Indexed by

\title{
TECHNOLOGICAL MODERNISATION PROSPECTS FORECAST OF THE MAIN INDUSTRIES IN RUSSIA BASED ON THE ASSESSMENT OF THE INNOVATIVE DEVELOPMENT LEVEL
}

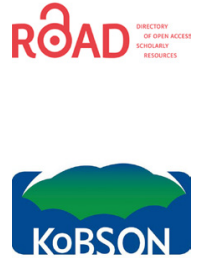

Yuri Anatolievich Doroshenko

Institute of Economics and Management, Department of Strategic Management, Russia

\author{
Anatoliy Andreyevich \\ Rudychev \\ Institute of Economics and \\ Management, Department \\ of Strategic Management, \\ Russia
}

\author{
Viktoriia Nikolayevna \\ Riapukhina \\ Institute of Economics and \\ Management, Department \\ of Strategic Management, \\ Russia
}

Key words: modernization, development of the industry, theory of Kondratiyev, upward and downward waves, forecasting, the economy of Russia

doi:10.5937/jaes0-34688

Cite article:

Doroshenko Anatolievich Y., Rudychev Andreyevich A., Riapukhina Nikolayevna V., (2021) TECHNOLOGICAL MODERNISATION PROSPECTS FORECAST OF THE MAIN INDUSTRIES IN RUSSIA BASED ON THE ASSESSMENT OF THE INNOVATIVE DEVELOPMENT LEVEL, Journal of Applied Engineering Science, 19(4), 1143 - 1149, DOI:10.5937/ jaes0-34688

Online aceess of full paper is available at: www.engineeringscience.rs/browse-issues 


\title{
TECHNOLOGICAL MODERNISATION PROSPECTS FORECAST OF THE MAIN INDUSTRIES IN RUSSIA BASED ON THE ASSESSMENT OF THE INNOVATIVE DEVELOPMENT LEVEL
}

\author{
Yuri Anatolievich Doroshenko ${ }^{*}$, Anatoliy Andreyevich Rudychev'2, Viktoriia Nikolayevna Riapukhina ${ }^{3}$ \\ Institute of Economics and Management, Department of Strategic Management, Russia
}

This article presents the theoretical foundations of the organic modernization and the development tendencies of the main branches of the industry in the economy of Russia. The prospects for the modernization of the industry are assessed by the criteria for the dynamics of the production and exports. According to the theory of Kondratiyev, on the basis of the trends in these indicators, upward and downward waves are identified. In compliance with Faltsman method, the forecast showed the growth and expediency of modernization of grain farming, housing construction complex, and motor-car industry. But it wasn't revealed the prerequisites for the growth of the petroleum industry and the military and industrial complex. The results of the study represent practical recommendations for the industrial development strategies.

Key words: modernization, development of the industry, theory of Kondratiyev, upward and downward waves, forecasting, the economy of Russia

\section{INTRODUCTION}

Modernization is the key to the industrial development. It affects institutional foundations and creates favorable conditions for the inflow of the private investment (for example, for the revival of industry in the areas that had previously been withdrawn from the economic cycle). Many researchers believe that modernization is a centuries-old historical process of the innovative activities caused by the endogenous (internal) factors [1]. Technological modernization is one of the various areas of the industrial modernization. The conditions of the technological modernization are the following: 1) improvement of productive forces; 2) dramatic increase in the level of technology; 3 ) technological reequipment of the economic sectors; 4) an increase in the share of the industries with high and medium levels of technology; 5) an increase in open-mindedness to innovation. The concept of modernization refers only to the most recent stage of progress. For this reason, modernization implies a revolutionary transition from the pre-industrial development to the industrial (or capitalist) one and then from industrial to the post-industrial (or post-modern) development. Modernity emerged after the industrial revolution and postmodernity appeared after the information revolution. Although modernity is not identical to progress, modernization generally means 1 ) rationalism, 2) estimation, 3) urbanization, and 4) industrialization. At the same time, the process of modernization can be organic, prepared by the previous development and which starts under the influence of changes in culture and consciousness, and non-organic, which is a reaction to an external challenge and which shows itself in the form of the "catching up" development. The purchase and leasing of foreign equipment and technologies, use of foreign intellectual property, studying abroad, recruitment of foreign specialists, and investment are integral aspects of non-organic modernization, which ultimately leads to a restructuring in the social and political spheres [2]. The organic or non-organic nature of modernization can be one of the areas of the comparative analysis of the industrial development practices. In general, technological modernization implies differences in the organizational models, and the situational market factors determine the implementation potential of these organizational models, which is evident from the historical experience. In this case, there are the following analysis factors: 1) the demand motivating mechanism for the social and economic transformations; 2) the driving forces of the organizational and economic transformations; 3) modernization of the intellectual capital. The characteristics of the stages of organic modernization represent the results of such analysis and also identify the main components [2].

The period from the XIV century to 1780 stands out as the first phase. The main motive for the development was the emergence of the market, the efficient demand for a cheap mass product, which led to the establishment and spread of manufacturing. At the same time, the driving force of modernization was the improvement of the organization of labor, based on the isolation of different production sectors, the widespread use of the division of labor and temporary work. The increase in intellectual capital was due to the transmission of knowledge in the family "from sire to son" while working, based on mentoring and personal experience. The systematic education was rare in this historical period. The second phase covers the period from 1780 to 1840 . The demand for cheaper, higher quality and more diverse consumer goods was the basis for the development mechanism. It determined 
the transition from manual labor to machinery, from manufactory to factory production; from a predominantly agricultural economy to the industrial production (industrial revolution). The most important type of transformation was the mechanization of labor in the textile industry, the use of a cheap resource (cotton) for the mass production. It is interesting that for the first time in the history, universities for nobles appeared and workers were trained at the working places. The initial phase of the 3rd stage covers the period from 1840 to 1890. Rapid urbanization, changes in the structure of consumption, forms and methods of work, the lifestyle of the population, and the emergence of national financial systems led to setting new standards for the financial and economic activities. All this created the basis for demand on social and economic transformations which became apparent in developing mass production technologies based on the mechanization of labor in the coal and steel industries, focusing on the mass resources and universal machinery. At this time, the network of universities was expanding, the first technical universities with engineering specialties appeared, and public primary education was also developing. The last phase of the 3rd stage covers the period from 1890 to 1940 . At this time, the formation of modern-type cities, a global financial system, demand for the movement of factors of production, as well as the demand for innovations that ensure the transformation of urban infrastructure, logistics, corporate structure based on new production and organizational technologies and the emergence of urban agglomerations took place. Robust production growth, mass steel production, industrial technologies for the production of non-organic chemical products enabling the production of new materials, the development of the motor-car industry, and telecommunications formed the basis of the motivational mechanism. Rapid development of universities as well as the emergence and formation of research laboratories in companies, specialized research institutes and transition to the public secondary education took place. The initial phase of the 4th stage covers the years 19401990. The massive formation of the urban agglomerations, the final globalization of commodity markets, and acceleration of the globalization of the production factors set new standards for consumer demand and production activities in the world. The structure of the mass consumer demand is changing, including growing demand for cars and organic chemicals, household electrical appliances, the need to improve communication systems and processes, urban and industrial infrastructure that determine the differentiation and global distribution of factors of production. At this time, multinational companies are the dominant factor in the development of the manufacturing sector, and the development of microelectronics and mechanics allows a dramatic expansion of the complex automation of the working processes. The scientific and technological development of petrochemistry has made it possible to develop materials with specific properties. Computers and space communications have made it possible to update the communications system. Higher education is becoming more available and due to this factor, the volume of scientific research in the public sector and corporations is increasing. The spread of flexible forms of production organization has led to increased creativity in the activity of employees. The final phase of the 4th stage began in 1990 and it is assumed to be finished by 2040 . We are witnessing the emergence of a crisis in some previously successful urban agglomerations and the final globalization of the production factors market. There is reassessment of availability of the natural resources, transition to their economic use, revision of the role of the traditional methods and technologies for mining, exploration, and processing of minerals. The search for innovative solutions in the organization of the industrial and urban infrastructure, logistics, and business development determines the emergence of a new way of life that places new demands on technologies and goods, including a new social management system. The most important organizational and economic change of this stage is the spread of the network organizational structures, network production technologies, transition to the distributed and flexible management systems in the economy and social sphere, an increase in the efficiency of the communication processes due to the massive spread of the computer equipment and technologies in the field of production, as well as in the field of science and research, enormous changes in the traditional industries based on information technology, flexible automated systems, nano and biotechnology. Improvement of the effectiveness of the institutional environment becomes one of the crucial factors of the economic development. During this period, there should be an expansion of the share of the international and inter-country scientific research, an increase in the role of the dual-purpose scientific research, development of the scientific research in interdisciplinary fields, deterioration of the quality of mass higher education, improvement of the quality and provision with the equipment of "special" research fields which promise a flow of innovations. The Russian renovation experience has also certain historical premises. In the 1950s and 1960s, Russia laid the foundations for the modern industrial development, space exploration, aircraft construction, nuclear industry, missile industry, submarine production and many other areas, which had an international effect. The energy crisis of the 70s caused a surge in the development of the resource-saving technologies in Western countries and a lag in Russia against the background of the demographic crisis and, accordingly, a decrease in the growth rate of labor resources. The result of the concentration of forces and resources enabled two directions: the military-industrial complex and the fuel and energy complex, which created the conditions for the development. All other spheres of activity, both economic and, in particular, social, developed according to the leftover principle and gradually reached an extreme stage of the technological underdevelopment and neglect [3]. In 2008 - 
2010, the country's leadership opted for the optimal model of gradual modernization to strengthen its position in terms of growth of the wealth and economic development [4]. In 2021, the national and regional development strategies with a duration of 2030 are being developed, which could be a decisive step towards leadership positions at least in a few sectors. However, to renovate the economy, the technological backlog must be overcome [5]. The economy itself must generate innovations, which is essential for the organic development. Therefore, nowadays it is urgent to select promising industries in order to support their priority growth and transformation. However, to keep the economy back on track, it is necessary to overcome the technological gap.

\section{METHODOLOGY}

The choice of perspective branches cannot be random. First, according to the genetic concepts of Kondratiyev N.D. about "heredity" and inertial growth, the development of industry within a large cycle is accompanied by either an upward or downward wave. Since both upward and downward waves are projecting on the future development, the theory of Kondratiev has the power of prediction. According to this theory, the future development is a social and economic genesis, which includes three types of processes: inertial growth ("heredity"), spontaneous changes ("variability"), the directed influence of the state on both. The deviation from the general trend characterizes the dynamics of a long-term change in the economic environment [6]. Secondly, according to the methodology of V.K. Faltsman, it is advisable to take into account the availability of skills and competitiveness in a particular industry sector, as well as in the related industries [7]. In order to analyze the nature of the waves the following modern stages are marked out: the transitional economy (1992-1999), the market economy (2000-2014), the oil crisis and the sanctions (2015-2017). The upward or downward trend is determined by adjusting the dynamic range of economic indicators, freeing it from onetime fluctuations. Competence indicators are the production volumes of domestic equipment production on the domestic and world market compared to its import. The higher the position of domestic production on the domestic and, especially, world markets, the better the conditions for the "catching-up" development option. The market can obtain an assessment of competitiveness, just as a comparison of the level of domestic and foreign equipment and technology can obtain the assessment. In the absence of competencies and other conditions for Russian production, the only way to increase production is to import equipment and technologies in exchange for oil and other mineral raw materials. If the import is i ncreasing, then either the option of import orientation or "catch-up" development is possible. [7]. The strategy of industrial development in Russia proposes realization of three possible options: 1) scientific and technological leadership based on the Russian research and development; 2) inertial import-oriented development, under retaining in the future an orientation towards the import of finished equipment; 3) "catching-up" development: the competitiveness of a product increases thanks to the use of foreign scientific and technological achievements and direct investment. Within the framework of the WTO, this option is realized by the establishment of industrial assembly enterprises, followed by the gradual replacement of the imported components and materials with home products (Russian localization of assembly).

\section{RESULTS AND DISCUSSION}

Within the analysis of perspective industries, it is advisable to consider the leading sectors of the Russian economy, which include the oil industry. In the 70s of the XIX century, with the creation of the oil industry V.G. Shukhov made great contribution and became the author of the world's first classical scientific theory of pipeline design, construction and operation, which he implemented in 1878 during the construction of an oil pipeline from the Apsheron Peninsula to the outskirts of present-day Baku. The significant growth of the oil industry began in the 50-60s and reached its peak in the 80 s of XX century. In the geopolitical context, in the 90-99s, stable revenues from oil, among other factors, contributed significantly to maintaining the country's integrity. Even today, up to three-quarters of the produced Russian oil is exported, and half of the export revenues are precisely the revenues from oil exports. During the crisis years (2009, 2014) oil exports continued to grow, but the revenues decreased due to falling prices. Nevertheless, the inertia of the upward wave helped the industry get out of the crisis. The last peak was recorded in 2018, after which economists predict a decline due to the market saturation and depletion of traditional fields. The dynamics of oil prices cannot be predicted, therefore against the background of an emerging downward wave due to saturation and depletion of traditional fields; it is not reasonable to expand capacity and do modernization to increase volumes, but it is reasonable to maintain a minimal increase (e.g., at the level of $1 \%$ ) until 2030 and then develop the Arctic deposits [8]. Although Russia can be considered a grain power which produces up to $5 \%$ of the world's grain, the grain market in Russia is still in its infancy due to the instability and imbalance of demand and consumption. Historically, only since 1950, thanks to oil exports, the country had the opportunity to buy rather than sell its grain. From the period of 1976-1980 to $1986-1990$ the volume of the grain production doubled. Then the structural crisis in the 90 s of the XX century led to recession and deficit until 1998. The country lacked grain and, at the same time, they spent more on livestock feeding than the countries with the developed economies, which led to the loss of food safety. However, the upward wave that began in 1995 led to the agricultural reform in 1997 and, despite the negative consequences of accession to WTO, resulted in a positive balance of cereal imports and exports in 2002 and a maximum increase in production in 2017, when exports also reached its maximum. 
As a result of the economic reforms, effected one after another, upward waves followed, which made it possible to realize the turning point and prove the effectiveness of investments in agriculture. There was a substitution of grain exports, in contrast to the early substitution trend of grain imports, while the low exchange rate of the ruble encouraged exports. In 2020, the country reached the second highest peak in grain production. It is impossible to predict the grain market due to the unpredictability of weather conditions. However, due to the possibility of replacing oil exports with grain exports, it is advisable to modernize the agricultural sector, for which it is necessary to restore the production of the domestic agricultural equipment and machinery [9].

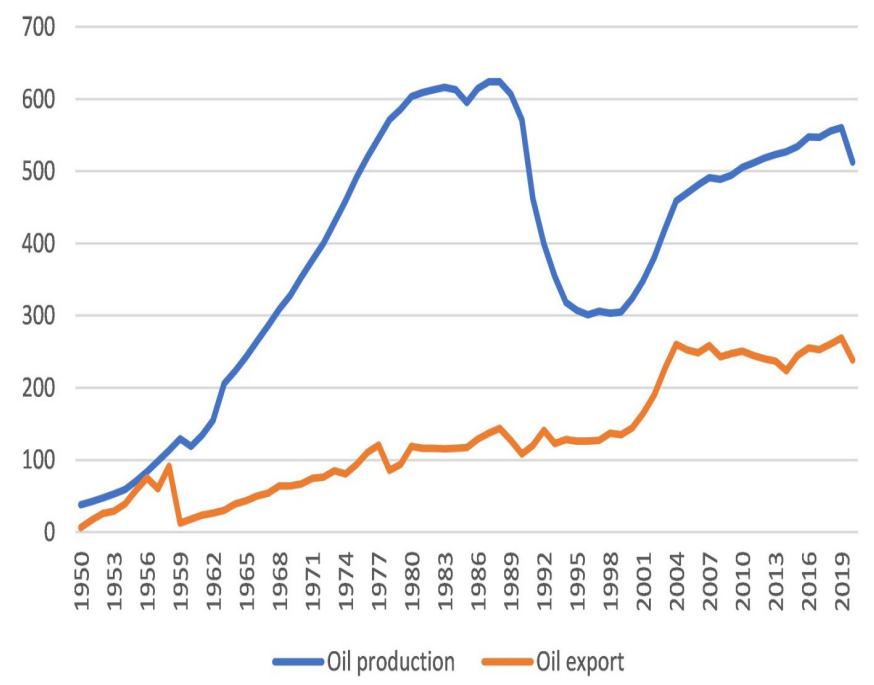

Figure 1: Oil production and export in the USSR and the Russian Federation for the period 1950 - 2020 (million tons)

In the construction industry, the upward wave of the 1960s occurred due to the accelerated industrial prefabricated construction. However, these buildings had a limited useful life and a low level of improvement. During the crisis period (1991-1999) the input of the total area of housing per 1000 population was insufficient. With the rise in oil prices, the commissioning of housing increased by one and a half. In 2017, the rehousing of the population and the demolition of dilapidated residential buildings built in 57-68 years of the twentieth century caused a new upward wave. Although this shift is not enough to eliminate the backlog accumulated in the past since the stock of dilapidated and hazardous housing is constantly increasing. However, it expects the upward wave to last until 2030. There are at least two conditions that need observation in order to solve the housing problem in Russia. The first one is the elimination of the dilapidated and substandard housing and the second would be to increase the average supply of housing compared with the developed countries. Additional opportunities for increasing housing construction are opening up the growth of the housing affordability index. In recent years, this fig- ure in Russia has decreased by half. The affordability of housing has grown significantly and there appeared the possibility of further growth in housing construction by attracting funds from the population. However, the projection for the possibility of covering the minimum dwellings retirement and the housing construction growth is pessimistic because it is necessary to increase the volume by another quarter. Modernization based on the imported equipment undoubtedly has an advantage over conservation and accumulation of technological backlog. Even so, the enormous scale of the road construction, construction of traffic facilities, earthworks and agricultural works create conditions in Russia for the transition in the future from the import-driven to "catch-up" development of the equipment production necessary for these areas of activities as is the case with the motor-car industry [10].

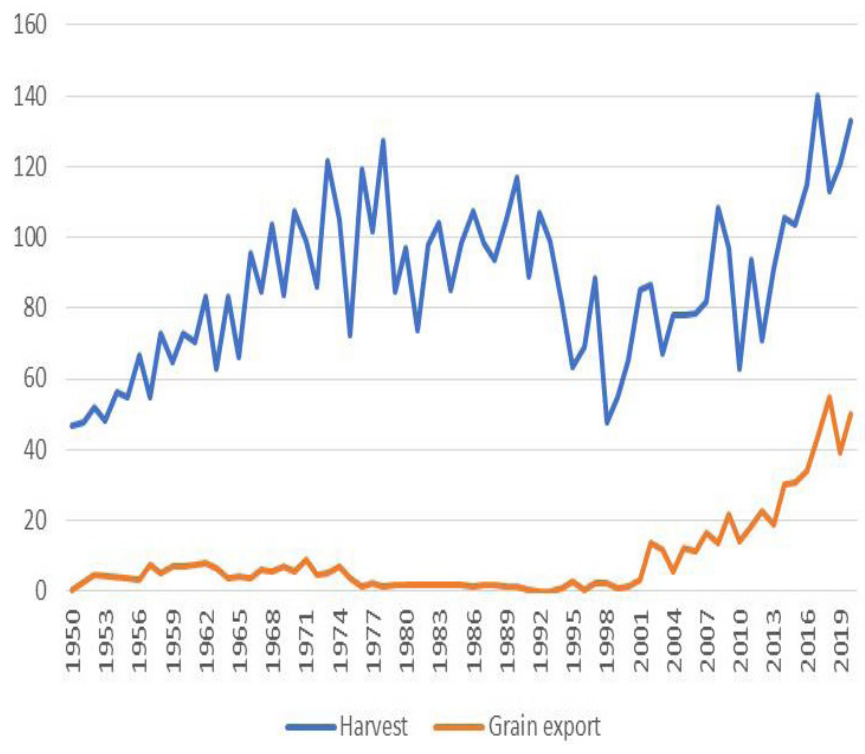

Figure 2: Harvest and export of grain in the USSR and the Russian Federation for the period 1950 - 2020 (million tons)

700

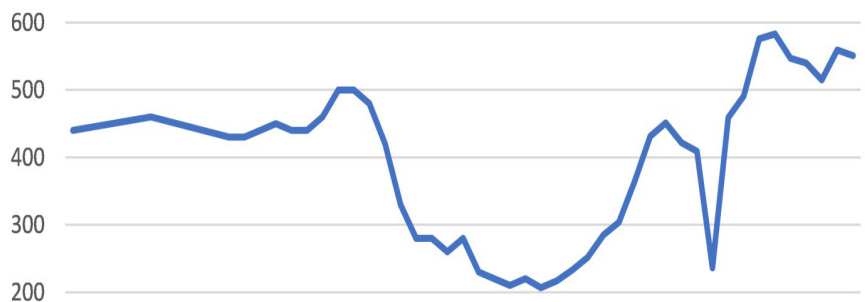

100

0

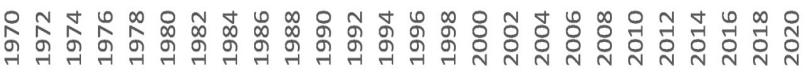

Residential buildings

Figure 3: Total area commissioning for the residential buildings per 1000 population in the USSR and the Russian Federation for the period 1950 - 2020 (sq.m.) 
The dynamics of the Russian military-industrial complex should take into account the consequences of the arms race that caused the upward wave. The negative features of the transitional period are the possibility of a loss of scientific and technical potential due to the decline in production, employment, investment and state procurement. When the focus from armament industry moved to the civilian industry, the expected transition did not occur. The modernization program of the military-industrial complex from 2011 to 2020 provided unique advantages and conditions for an upward wave. According to the US Armaments Ministry, Russia is superior in the production of most weapons, i.e priority grade taking into account that the weapons are not always compatible with the Western systems and standards. During the 2014 crisis, Russia, unlike other oil exporters, increased military expenditure. One of the possible reasons for the high inertia of the Russian defense budget is the large proportion of the sophisticated military equipment - aircraft, missile-carrying ships, etc. The long production cycles of their development and manufacture limit the possibility of mobile adjustment of the weapons production program depending on the current changes in oil prices. In connection with the completion of the rearmament program in 2020, they can expect a downward wave in the period of 2018-2030. The plan is to reduce the share of the military spending in GDP to an optimal level of $3 \%$. The participation of the civilian products in the military-industrial complex will increase from 16 to $50 \%$. At the same time, Russia expects a trend of increasing exports to India, China and other countries where these products compete with price and quality. Insufficient rapid capacity renewal compared to the growth of demand and orders [11] can be a threat here.

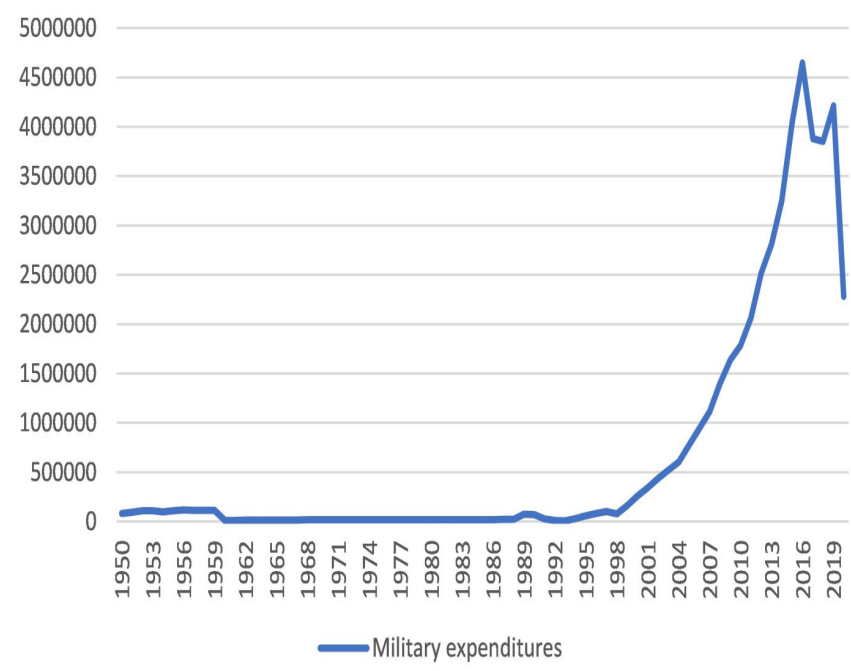

Figure 4: Military expenditures in the USSR and the Russian Federation for the period of 1950 - 2020 (million rubles)
Russian experience in motor transport and civil aviation illustrates the course of the industrial evolution with development within the framework of non-organic modernization. The acquisition of new and used (second-hand) equipment allowed the accumulation of experience and funds for the purchase of new equipment. Modernization let Russia develop its own assembly production for new foreign models of the equipment and improvement of its domestically produced ones. After the turnkey construction of the Fiat-Lada plant in 1966, another upward wave started. The construction of foreign motor plants in Russia, assembly production, modernization, increase of production, and imports triggered the next upward wave. After 2015, the trend was in direct proportion to the growth in the welfare of the country and the population. As of the beginning of 2021, the level of car availability in Russia is 313 cars per 1000 inhabitants under the conditions of the delayed demand. The growth of domestic production displaces imports, while imports reduce production [12].

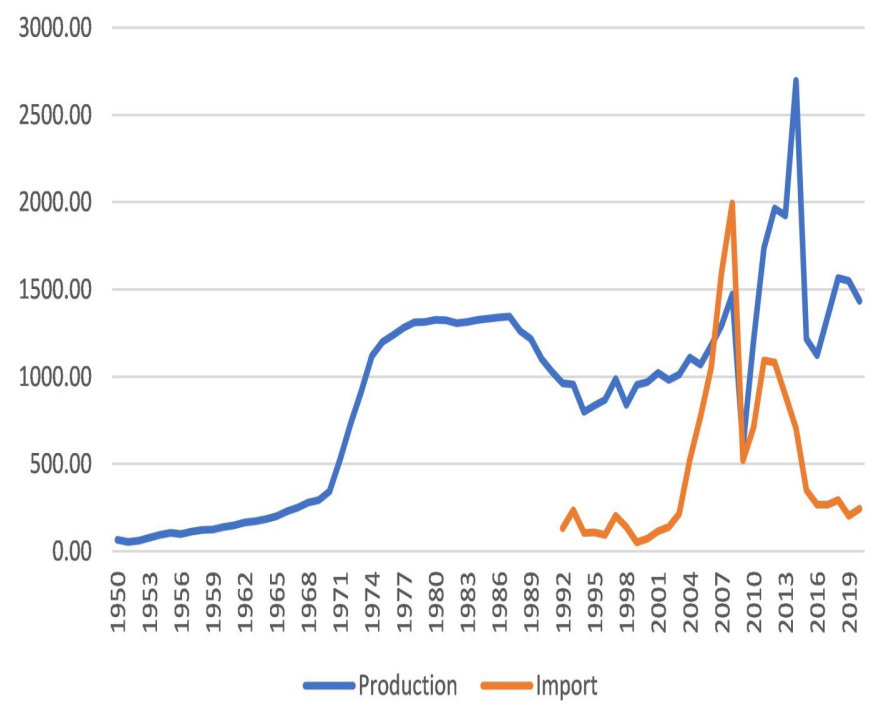

Figure 5: Production and import of cars in the USSR and the Russian Federation for the period of 1950 - 2020 (in thousands of units)

\section{SUMMARY AND CONCLUSION}

Based on the results of the analysis, it is possible to predict the extent to which the dynamics of production and exports of different industries depend on each other. The upward wave of the oil industry and the military-industrial complex began in the 1960s, but we still feel their influence. During the same period, there was an upsurge in the building construction industry due to the use of prefabricated reinforced concrete structures. With the rise in oil prices in 2000-2014, there was a boom in other industries. The decline in oil prices that occurred in 20152017 did not have a significant negative impact on other 
industries, with the exception of the automotive industry, and during this period the production and export of cereals increased. The rise in oil prices creates conditions for the modernization of the military-industrial complex, while the reduction of the burden of the military spending on the economy makes it possible to prevent or slow down a downward wave when oil becomes cheaper. Grain exports can partially offset oil exports, while the motor-car industry and the housing construction complex can do this at the expense of the population's previous savings by creating the necessary conditions [13]. Russian experience has shown that additional conditions are needed to move from one phase of modernization to another, such as: 1) a favorable investment environment; 2) availability of scientific and production competencies; 3) a large-scale market, available and relatively cheap labor forces of an adequate quality and training; 3 ) land, available in price and quality, energy resources, raw materials, and other production resources; 4 ) international economic integration, ensuring free competition in the external environment. Purchasing imported equipment, Russia acts as an active user: it trains personnel, creates software, develops trade, repair services, sets up cellular companies, etc. [3]. The perspectives of the individual industries development set the conditions for choosing between the strategy of the traditional import-oriented or catching-up option of the innovative development. These both options are based on the foreign scientific and technical achievements and aimed at reduction and ultimate elimination of the technical backlogs. But the catching-up option assumes the innovative development of the Russian production, the transfer of the Western technologies to Russia, and the import-oriented one - for the purchase of the foreign equipment and technologies for modernization. Under import-oriented option, the importing country does not act as a producer, but as an active beneficiary of foreign achievements that create the necessary conditions for modernization. The optimistic version of the "catch-up" development assumes that domestic industrial construction along the technological chain will cause technological advancement in the related industries (production of components, machinery, materials). It will result in an increase in the technological level, quality and competitiveness of the products of many related industries and the Russian production in general. The pessimistic version assumes the fact that the inertia of the technological backlog in the environment of the domestic production will be significant that it will not be possible to overcome it by borrowing technologies, as it happened with the introduction of FIAT production in Russia. Foreign equipment will still predominate in the Russian production, and it will remain in assembly. But even in this case, the industrial assembly will bring Russia new jobs and the production of the competitive equipment of foreign brands. The process of the technological modernization has begun and it takes place due to the import-oriented option. An import-oriented modernization is not something new for Russia. At present, only the scale of the displacement of the domestic production of the individual technical facilities of modernization by the imported equipment is striking. The possibilities for further displacement of the Russian production by imports are limited or even impossible in these areas [14]. V.K. Faltsman's forecast as far as 2030 suggests growth against the background of an increasing wave and the possibility of modernizing grain economy, the construction and housing complex, and the motor-car industry. At the same time, the conditions for significant growth in the oil industry are not apparent and the production volumes will maintain a slight increase for export. The conditions for the significant growth of the military-industrial complex are also not evident [7]. There is an expectation for the decrease of the volume of the arms production, but in order to develop exports costs will not be reduced. It is advisable to reduce modernization efforts in these sectors to a supportive character [15; 16]. Therefore, the main tasks of the Russian economy as far as 2030 include: maintaining oil production at the achieved level; an increase in the production of the civilian products at the armament enterprises, which will compensate for the decrease in the state defense orders; solving the housing problems; the recovery of the domestic motor market and the growth of the motor-car exports; a significant increase in grain collection and export.

\section{ACKNOWLEDGMENT}

This study has been conducted according to the state order of the Ministry of Education and Science of Russia (FZWN-2020-0016).

\section{REFERENCES}

1. Kovaleva, I. P. (2015). Modernization theory and practice. New word in science and practice: hypotheses and approbation of research results, vol. 20, 89-96, from https://cyberleninka.ru/article/n/teoriya-i-praktika-modernizatsii, accessed on 2021-0908.

2. Batukova, L. (2014) Prerequisites for successful modernization in Russia. Science and innovations, vol. 131, 34-36, from https://cyberleninka.ru/article/n/predposylki-neobhodimye-dlya-provedeniya-uspeshnoy-modernizatsii-v-rossii, accessed on 2021-08-14.

3. Faltsman, V. K. (2012) Variants of technological modernization of Russia. Modern Europe, vol. 4, no. 52, 5-18, from https://www.elibrary.ru/download/ elibrary_18127453_81524789.htm, accessed on 2021-08-07.

4. Doroshenko, Y. A., Starikova, M. S., Riapukhina, V. N. (2021) Models of Regional Development in Russia: Level of Industrialisation and Innovative Performance. Inzinerine Ekonomika-Engineering Economics, vol. 32, no. 3, 247-257, DOI: 10.5755/j01. ee.32.3.25897 
5. Malykhina, I. O., Riapuhina, V. N., Chizhova, E. N., Rozdolskaya, I. V. (2020) Neo-industrialization as the Bases of the Innovative Trajectory of the Development of Russian Industry before and during the Coronavirus Disease-19 Pandemic. Open Access Maced J Med Sci, vol. 8, no. E, 685-92, DOI: 10.3889/oamjms.2020.5676

6. Kondratiev, N. D. (2002). Conjuncture supercycles and the theory of foresight. International ND Kondratiev Foundation, Moscow.

7. Faltsman, V.K. (2018) Key tasks and prospects for the Russian economy development in line with the "Kondratieff supercycles". Problems of forecasting, vol. 4, no. 169, 27-37, from https://cyberleninka.ru/ article/n/klyuchevye-zadachi-i-perspektivy-razvitiya-rossiyskoy-ekonomiki-v-rusle-kondratievskih-bolshih-tsiklov, accessed on 2021-07-08.

8. Shapovalov, D. A., Khabarov, D. A., et al. (2020) Russian market of oil and oil products. International Journal of Applied Sciences and Technologies "Integral", vol. 3, from https://cyberleninka.ru/article/n/ rossiyskiy-rynok-nefti-i-nefteproduktov, accessed on 2021-10-24

9. Surenkov, V. A. (2019). Russian grain market. Development specifics. Innovations and investments, vol. 7, from https://cyberleninka.ru/article/n/rossiyskiy-rynok-zerna-spetsifika-razvitiya, accessed on 2021-10-24.

10. Kenchadze, D. D. et al. (2020). Construction in Russia 2020. Rosstat, Moscow, from https://rosstat.gov.ru/storage/mediabank/tASKTSkO/Stroitelstvo_2020.pdf, accessed on 2021-10-24.
11. Romanov, M. I. (2021). Development dynamics of the Russia military-industrial complex: problems and prospects. Innovations and investments, vol. 2, from https://cyberleninka.ru/article/n/dinamika-razvitiya-oboronno-promyshlennogo-kompleksa-rossii-problemy-i-perspektivy, accessed on 2021-10-24.

12. Zakrevskaya, Ya. N. (2020). Present automotive industry in Russia. Education and law, vol. 7, from https://cyberleninka.ru/article/n/avtomobilnaya-promyshlennost-rossii-na-sovremennom-etape, accessed on 2021-10-24.

13. Faltsman, V. K. (2019) What if Russia runs out of own oil resources? Voprosy Ekonomiki, vol. 4, 152160, DOI: 10.32609/0042-8736-2019-4-152-160

14. Faltsman, V. (2017) Overcoming the Crisis in Russia's Foreign Trade, Russian Politics \& Law, vol. 55, no. 6, 436-456, DOI: 10.1080/10611940.2017.1574501

15. Doroshenko, Y. A., Malykhina, I. O., Somina, I. V. (2020) Methodology of the Formation of a Comprehensive Support Mechanism of Innovation and Investment Development in the Region. In: Karabegović I. (eds) New Technologies, Development and Application III. NT 2020. Lecture Notes in Networks and Systems, vol. 128, DOI: 10.1007/978-3-03046817-0_103

16. Doroshenko, Y. A., Minaeva, L. A., Somina, I. V., Glagoleva, N. N. (2020) Mechanism of Stimulate the Growth of Highly Competitive Technology Business. In: Karabegović I. (eds) New Technologies, Development and Application III. NT 2020. Lecture Notes in Networks and Systems, vol. 128, DOI: 10.1007/9783-030-46817-0_102 